\title{
Efektifitas Pemberian Proton Pump Inbibitor pada Bayi dan Anak dengan Laringomalasia
}

\author{
Riza Sahyuni, Bambang Supriyatno, Syahrial MH, Aria Kekalih* \\ Departemen Ilmu Kesehatan Anak, "Departemen THT, " Departemen Ilmu Kedokteran Komunitas FK Universitas Indonesia/ RS \\ Dr. Cipto Mangunkusumo
}

\begin{abstract}
Latar belakang. Laringomalasia merupakan kondisi kelemahan struktur supraglotis yang menimbulkan gejala stridor. Umumnya, penyakit penyerta laringomalasia adalah refluks laringofaring (RLF). Pemberian omeperazol dapat memperbaiki gejala regurgitasi dan stridor serta memperpendek durasi perjalanan alamiah laringomalasia.

Tujuan. Mengetahui efektifitas omeperazol pada bayi dan anak dengan laringomalasia.

Metode. Uji pre-post experimental pada 42 subyek yang mendapat omeperazol $2 \times 2 \mathrm{mg} / \mathrm{kg} / \mathrm{bb}$ selama 3 bulan

Hasil. Pemberian omeperazol pada laringomalasia dengan gejala berat, 58,8\% mengalami perbaikan. Pemberian omeperazol pada laringomalasia dengan RLF positif, 58,3\% mengalami perbaikan. Tampak perbaikan bermakna secara statistik pada perbandingan nilai awal dan akhir reflux finding score (RFS) dan laringomalacia score symptom (LSS)

Kesimpulan. Prevalensi RLF positif berdasar RFS menurut Belafsky adalah 24,6\% dan berdasar LSS dengan gejala berat adalah 44,6\%. Efektifitas pemberian omeperazol selama 3 bulan terbukti efektif pada perbaikan nilai LSS, RFS dan status gizi. Sari Pediatri 2017;18(6):459-67
\end{abstract}

Kata kunci: refluks laringofaring, reflux finding score, laringomalacia score symptom (LSS), laringomalasia

\section{The Effectivity of Giving Proton Pump Inhibitor to The Babies and Child with Laryngomalacia}

Riza Sahyuni, Bambang Supriyatno, Syahrial MH, Aria Kekalih ${ }^{* *}$

Background. laryngomalacia is condition of floopy supraglottis stucture and it causes symptom stridor. In general, the comorbidity of laryngomalacia is laryngopharyngeal reflux (LPR). The giving of omeperazole can improve the symptom of regurgitation and stridor and shorten the duration of natural disease of laryngomalacia.

Objective. Knowing the effectivity of giving omeperazole to the babies and children with laryngomalacia.

Method. Test pre-post experimental on 42 samples that have been given omeperazole $2 \times 2 \mathrm{mg} / \mathrm{kg} / \mathrm{bw}$ for 3 month.

Result. Giving omeperazol on laryngomalacia with severe symptom showed the improvement of 58,8\%. Giving omeperazole on laryngomalacia with RLF positive showed the improvement of 58,3\%. Seemed statistically significant improvement in comparison pre and post score reflux finding score (RFS) and laringomalacia score symptom (LSS).

Conclusion. The Prevalence of positive LPR based on RFS is $24,6 \%$ and with severe symptom is $44,6 \%$. The effectivity of giving omeperazole for 3 month has proved effective based on the improvement of value LSS, RFS and nutrition status. Sari Pediatri 2017;18(6):459-67

Keywords: laryngopharyngeal reflux (LPR), reflux finding score (RFS), laryngomalacia symptom score (LSS), laryngomalacia

Alamat korespondensi: Dr. Riza Sahyuni, SpA. Departemen IKA FK Universitas Indonesia/RS Dr. Cipto Mangunkusumo, Jakarta. E-mail: sahriza@ yahoo.com 
Riza Sahyuni dkk: Efektifitas pemberian proton pump inhibitor (omeperazol) pada bayi dan anak dengan laringomalasia

S tridor saat inspirasi pada bayi umumnya disebabkan oleh laringomalasia, khas yang semakin memburuk pada posisi terlentang dan tipikal timbul setelah beberapa hari atau minggu setelah lahir. ${ }^{1-3}$ Penyakit penyerta terbanyak ditemukan pada laringomalasia (25\%-68\%) adalah refluks laringofaring (RLF). Refluks laringofaring adalah pergerakan isi lambung secara retrograd menuju laring, faring, dan saluran nafas atas dan mengakibatkan timbul gejala dan tanda klinis yang bervariasi. ${ }^{4-8}$

Studi Orenstein yang dikutip oleh Thompson ${ }^{8}$ menjelaskan bahwa ada hubungan sebab akibat antara gejala stridor dengan RLF. Studi Contencin dan Nancy serta didukung studi Little yang dikutip oleh Lovinsky ${ }^{9}$ menjelaskan bahwa stridor merupakan faktor prediksi RLF yang harus dibuktikan dengan pemeriksaan pHmetri. May ${ }^{11}$ melakukan systemic review 8 literatur mengenai hubungan penemuan klinis pada laring dan trakea, diperoleh bahwa tanda edem dan eritem aritenoid, hipertrofi tonsil lingual, edem postglotik dan edem plika vokalis merupakan tanda klnis RLF. Tanda klinis tersebut dapat dipergunakan membantu diagnosis dan membantu evaluasi tata laksana RLF pada bayi dan anak.

Gejala RLF pada anak sangat bervariasi terutama pada bayi. Sistem skoring gejala RLF oleh Belafasky yaitu reflux symptom index (RSI) dan reflux finding score (RFS) adalah sistem skoring menilai 8 penemuan klinis berdasar hasil pemeriksaan laringoskopi yang dipakai untuk menegakkan diagnosis RLF pada orang dewasa, tetapi sistem skoring ini belum dilakukan validasi untuk bayi dan anak. ${ }^{6,12,13}$

Refluks pada pasien laringomalasia dengan masalah feeding harus diberikan terapi. Pemberian terapi acid supression dapat memperbaiki gejala dan memperpendek durasi perjalanan alamiah penyakit. Saat ini belum ada studi kontrol yang menunjukkan lebih efektif regimen terapi RLF pada pasien laringomalasia. ${ }^{2}$ Sebagian klinisi menganjurkan pemberian terapi acid suppression agar dapat memperbaiki akibat gejala regurgitasi dan mengurangi gejala stridor. ${ }^{4,14,15}$

Tujuan penelitian untuk mengetahui efektifitas pemberian obat proton pump inhibitor (omeperazol) pada bayi dan anak dengan laringomalasia.

\section{Metode}

Penelitian dilakukan sejak bulan Januari - Desember 2015 di Poliklinik Respirologi Anak dan Poliklinik
THT RS dr Cipto Mangunkusumo Jakarta. Dilakukan persetujuan penelitian (informed consent) dari orang tua pasien yang dijadikan sampel penelitian serta persetujuan dari Komisi Etik Penelitian Biomedis pada manusia Fakultas Kedokteran Universitas Indonesia. Kriteria inklusi adalah usia bayi 2 minggu - anak usia 5 tahun, didiagnosis menderita laringomalasia dan mendapat persetujuan orang tua. Kriteria eksklusi adalah mempunyai penyakit sesak nafas berat, memerlukan perawatan NICU/PICU, laringomalasia berat yang memerlukan tindakan operatif, pasca operasi trakeostomi, tidak memungkinkan dilakukan pemeriksaan laringoskopi, alergi terhadap obat omeperazol dan terdapat abnormal laring lainnya.

Pemeriksaan laringoskopi dilakukan untuk menegakkan diagnosis laringomalasia, tipe, RFL dan ditentukan skor RFS dan LSS awal dan akhir penelitian, serta dinilai status gizi subyek. Besar sampel penelitian didapat 42 subyek. Studi merupakan penelitian pre - post experimental test pada bayi dan anak dengan laringomalasia, sebelum dan sesudah pemberian omeperazol selama 3 bulan. Seluruh data dianalisis menggunakan program statistical packages for social sciences (SPSS) versi 21.

\section{Hasil}

Median usia subyek 8,5 bulan, usia termuda 1 bulan dan tertua 42 bulan. Proporsi subyek anak laki-laki lebih besar dibanding perempuan, 26 laki-laki dan 16 perempuan. Berdasarkan riwayat masa gestasi, subyek kelompok perlakuan 36 dengan riwayat gestasi cukup bulan dan 6 dengan gestasi kurang bulan. Berdasarkan riwayat cara persalinan, 26 dengan riwayat persalinan spontan normal dan 16 dengan tindakan, seperti seksio sesaria dan vakum ekstraksi. Berdasar riwayat berat badan lahir, 34 normal (sekitar 2500-4000 gram) dan 8 berat badan lahir rendah (BBLR) (sekitar 1500-2499 gram, dan berat lahir sangat rendah (BBLSR) (1000-1499 gram). Kondisi status gizi sebelum perlakuan, sebagian besar berstatus gizi kurang dan buruk, 34 subyek, dan 8 gizi baik. Rerata nilai LSS awal 4 (kisaran nilai 3-7). Bila dikategorikan menjadi gejala ringan dan berat, pada awal penelitian 17 subyek dengan gejala berat dan 25 gejala ringan. Rerata nilai RFS awal penelitan juga hampir sama, 2 (kisaran nilai 2-10). Bila dikategorikan ada tidak nya RLF, pada awal penelitian jumlah pasien RLF positif 12 dibandingkan non RLF 30 subyek (Tabel 1). 
Bila dikategorikan ada tidaknya RLF pada akhir penelitian, RLF positif 7 mengalami perbaikan dan 5 subyek tidak mengalami perbaikan. Pada non RLF, 14 mengalami perbaikan dan 16 subyek tidak mengalami perbaikan (Tabel 2).

Nilai RFS pada akhir penelitian juga tidak berubah bila dibanding dengan nilai RFS awal, yaitu rerata nilai RFS akhir 2 dengan kisaran 0-8 (Tabel 3 dan Gambar 1). Rerata nilai RFS dengan RLF positif pada awal penelitian 8 (6-12) dan perbaikan pada akhir penelitian $6(4-10), \mathrm{p}<0,001$

Pada Tabel 2 dan Gambar 2, rerata nilai LSS akhir penelitian $3,38 \pm 1,18, \mathrm{p}<0,001$. Bila dikategorikan

Tabel 1. Karasteristik subyek

\begin{tabular}{|c|c|c|}
\hline Karakteritik & & Subyek $(n=42)$ \\
\hline Usia (bulan) & & $8,5(1-42)$ \\
\hline \multicolumn{3}{|l|}{ Jenis kelamin } \\
\hline Laki-laki & & $26 / 42$ \\
\hline Perempuan & & $16 / 42$ \\
\hline \multicolumn{3}{|c|}{ Usia gestasi (bulan) } \\
\hline Cukup & & $36 / 42$ \\
\hline Kurang & & $6 / 42$ \\
\hline \multicolumn{3}{|c|}{ Jenis persalinan } \\
\hline Normal & & $26 / 42$ \\
\hline Tindakan \# & & $16 / 42$ \\
\hline \multicolumn{3}{|c|}{ Berat badan lahir } \\
\hline Normal & & $34 / 42$ \\
\hline Rendah $\wedge$ & & $8 / 42$ \\
\hline \multicolumn{3}{|l|}{ Status gizi } \\
\hline Baik & & $8 / 42$ \\
\hline Kurang $¥$ & & $34 / 42$ \\
\hline \multicolumn{3}{|l|}{ Nilai awal LSS } \\
\hline Ringan & & $25 / 42$ \\
\hline Berat & & $17 / 42$ \\
\hline \multicolumn{3}{|l|}{ Nilai awal RLF } \\
\hline Positif & & $12 / 42$ \\
\hline Non RLF & & $30 / 42$ \\
\hline \multicolumn{3}{|c|}{$\begin{array}{l}\text { Keterangan: \# Lahir seksio sesaria dan vakum ekstraksi } \\
¥ \text { Gizi kurang dan buruk } \\
\text { ^ BBLR dan BBLSR }\end{array}$} \\
\hline \multicolumn{3}{|c|}{ Tabel 2. Rerata nilai RFS dan LSS awal dan akhir } \\
\hline & Rerata & $\mathrm{p}$ \\
\hline \multicolumn{3}{|l|}{ Nilai RFS } \\
\hline Awal & $3(2-10)$ & $<0,001$ \\
\hline Akhir & $2(0-8)$ & (Wilcoxon test) \\
\hline \multicolumn{3}{|l|}{ Nilai LSS } \\
\hline Awal & $4,26 \pm 1,25$ & $<0,001$ \\
\hline Akhir & $3,38 \pm 1,18$ & (Paired T test) \\
\hline
\end{tabular}

berdasar berat ringan gejala maka tampak pada gejala ringan 11 mengalami perbaikan dan 14 subyek tidak mengalami perbaikan. Pada gejala berat, 10 mengalami perbaikan dan 7 subyek tidak mengalami perbaikan. Hasil pemeriksaan laringoskopi pada akhir penelitian juga didapatkan adanya perbaikan laringomalasia berupa sudah tidak adanya floopy (terkulai) epiglotis atau aritenoid, yaitu 4 subyek (Tabel 3).

Kondisi status gizi akhir penelitian tampak pada status gizi baik dan obesitas terdapat 2 mengalami perbaikan dan 6 subyek yang tidak mengalami perbaikan. Pada status gizi buruk marasmik dan gizi kurang terdapat 19 mengalami perbaikan dan 15 subyek yang tidak mengalami perbaikan (Tabel 4).

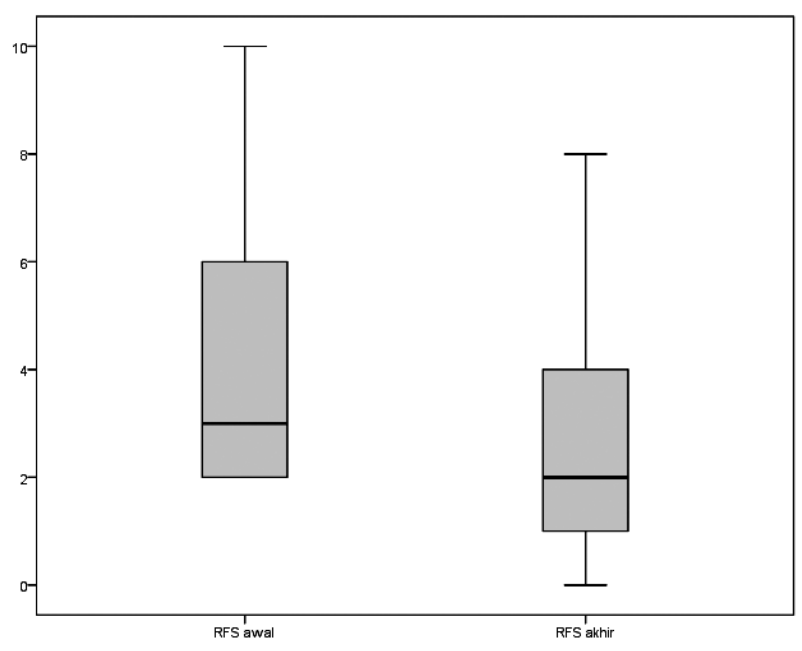

Gambar 1. Boxpot pre-post test nilai RFS awal dan akhir

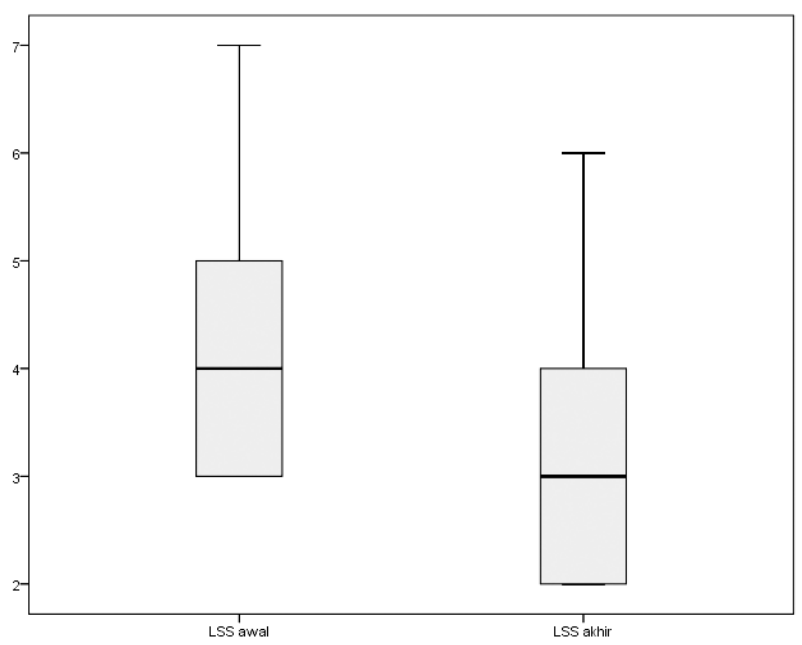

Gambar 2. Boxpot pre-post test nilai LSS awal dan akhir 
Tabel 3. Sebaran berdasar nilai akhir LSS dan hasil laringoskopi

\begin{tabular}{lc}
\hline Karakteristik subyek dg LSS & Omeperazol $(\mathrm{n}=42)$ \\
\hline Nilai akhir LSS* & \\
Gejala ringan & \\
Perbaikan & $11 / 42$ \\
$\quad$ Tidak ada perbaikan & $14 / 42$ \\
Gejala berat & \\
$\quad$ Perbaikan & $10 / 42$ \\
$\quad$ Tak ada perbaikan & $7 / 42$ \\
Hasil akhir laringoskopi ${ }^{* *}$ & \\
Perbaikan & $4 / 42$ \\
Tidak ada perbaikan & $38 / 42$ \\
\hline
\end{tabular}

Tabel 4. Sebaran status gizi pada akhir penelitian

\begin{tabular}{lc}
\hline Status gizi & Omeperazol $(\mathrm{n}=42)$ \\
\hline Status gizi akhir ${ }^{*}$ & \\
Gizi baik $^{\text {a }}$ & \\
$\quad$ Perbaikan & $2 / 42$ \\
$\quad$ Tidak ada perbaikan & $6 / 42$ \\
Gizi kurang ${ }^{\mathrm{b}}$ & \\
$\quad$ Perbaikan & $19 / 42$ \\
$\quad$ Tidak ada perbaikan & $15 / 42$ \\
\hline a Gizi baik dan obesitas & \\
b Gizi kurang dan buruk marasmik &
\end{tabular}

\section{Pembahasan}

Sebaran usia subyek tidak normal sehingga nilai rerata yang digunakan adalah median. Sebaran usia tidak normal karena sebagian besar subyek diambil dari saat subyek baru terdiagnosis dan saat usia datang ke RSCM yang berarti memiliki rentang usia tertentu. Median usia subyek adalah usia 8,5 bulan, termuda 1 bulan dan tertua 42 bulan. Belum ada laporan mengenai prevalensi kejadian laringomalasia berdasarkan usia pada anak. Studi Thompson ${ }^{16}$ menyatakan bahwa usia saat diagnosis berhubungan erat dengan berat ringannya gejala laringomalasia.

Hingga saat ini belum ada penelitian yang melaporkan mengenai predisposisi kejadian laringomalasia maupun hubungan kejadiannya pada jenis kelamin tertentu. Nasution ${ }^{17}$ melaporkan bahwa proporsi anak laki-laki yang menderita laringomalasia lebih banyak 1,6:1 dibandingkan anak perempuan dari 80 anak dengan laringomalasia. Penelitian oleh Thompson' pada 201 bayi laringomalasia juga melaporkan proporsi 1,4;1, lebih banyak pada anak laki-laki dibandingkan perempuan. ${ }^{16}$ Penelitian oleh
Edmondson ${ }^{18}$ pada anak usia di bawah 5 tahun dengan laringomalasia juga didapatkan proporsi anak laki-laki lebih banyak 1,4:1 dibandingkan perempuan.

Perbedaan rasio jenis kelamin mungkin dapat dijelaskan karena perbedaan karakteristik saluran nafas dan manifestasi klinis yang berkaitan dengan penyakit saluran nafas sepanjang siklus hidup manusia antara laki-laki dengan perempuan. Bayi perempuan cenderung mempunyai ukuran paru yang lebih kecil dan lebih mature, mempunyai bronkiolus lebih sedikit dan mempunyai risiko terjadi respiratory distress syndrome lebih kecil serta mempunyai force expiratory flow rates yang lebih besar. Hal tersebut disebabkan karena paru-paru bayi perempuan mempunyai respons lebih baik terhadap hormon yang mempercepat produksi surfaktan paru. Volume paru yang besar berhubungan dengan kecepatan udara saat inspirasi, sesuai dengan prinsip Bernoulli ${ }^{19}$ yang menjelaskan patogenesis terjadi stridor. Sebaliknya, bayi laki-laki mempunyai paru yang lebih besar dan mempunyai kecepatan udara saat inspirasi lebih cepat sehingga dapat menyebabkan tekanan negatif intra lumen yang menimbulkan terhisapnya jaringan supraglotis saat inspirasi.

Berdasarkan riwayat cara persalinan, 26 subyek dengan riwayat persalinan spontan normal dan 16 dengan tindakan, seperti seksio sesaria dan vakum ekstraksi. Perbedaan cara persalinan ini lebih menggambarkan kondisi sosial ekonomi keluarga subyek sehingga cara persalinan bukanlah faktor risiko laringomalasia.

Berdasarkan riwayat masa gestasi, 36 dengan riwayat gestasi cukup bulan dan 6 kurang bulan. Masa gestasi subyek penelitian sebagian besar cukup bulan. Laringomalasia pada umumnya ditemukan pada bayi cukup bulan atau hampir cukup bulan. Thompson ${ }^{16}$ melaporkan hasil yang hampir sama, yaitu bayi laringomalasia lebih banyak ditemukan pada bayi dengan riwayat cukup bulan. Penelitian oleh Whymark ${ }^{20}$ pada 76 bayi laringomalasia yang mendapat terapi supraglotoplasti hanya ditemukan 4 bayi kurang bulan. Berat lahir bayi dan maturitas subyek erat kaitan dengan maturitas sistem saraf pusat (SSP). Bayi dengan berat badan rendah dan prematuritas berisiko lebih besar terjadi kelainan neurologis dan tumbuh kembang yang nanti juga berkaitan dengan laringomalasia yang diderita subyek.

Status maturitas dianggap mempunyai pengaruh terjadinya laringomalasia, dijelaskan dengan teori 
gangguan neuromuskular. Nilai laryngeal pharyngeal sensory testing (LPST) pada bayi kurang bulan lebih tinggi dari normal, menunjukkan adanya gangguan neuromuskular pada kurang bulan. Namun, Thompson ${ }^{16}$ tidak memperoleh adanya hubungan antara masa gestasi dengan derajat gejala laringomalasia sehingga kesimpulan sementara bahwa masa gestasi bukanlah faktor risiko laringomalasia dan laringomalasia dapat ditemukan pada bayi kurang bulan.

Berdasarkan riwayat berat badan lahir, 34 berat badan lahir normal (sekitar 2500-4000 gram) dan 8 berat badan lahir rendah (BBLR) (sekitar 15002499 gram dan berat lahir sangat rendah (BBLSR) (1000-1499 gram). Nasution ${ }^{17}$ melaporkan bahwa bayi laringomalasia $85 \%$ mempunyai riwayat berat badan lahir normal >2500 gram. Hal ini juga sesuai dengan hasil penelitian Thompson ${ }^{16}$ yang melaporkan rentang BBL 800-5450 gram dengan nilai median BBL 3270 gram.

Studi Thompson ${ }^{16}$ menilai derajat gejala laringomalasia berdasar data demografi sampel dengan variabel data berupa jenis kelamin, ras, usia gestasi, jenis persalinan, berat badan lahir, nilai skor APGAR menit ke-1, nilai skor APGAR menit ke-5, usia saat awitan, usia saat diperiksa klinisi, usia saat ditegakkan diagnosis. Didapatkan hasil yang berhubungan bermakna dengan berat ringannya gejala disetiap kelompok variabel adalah skor APGAR menit ke-1, nilai skor APGAR menit ke-5, dan usia saat ditegakkan diagnosis. Diagnosis tipe laringomalasia ini adalah berdasar kelainan anatomis yang ditemukan pada hasil pemeriksaan laringoskopi dan tidak menggambarkan berat-ringannya derajat laringomalasia. Pada beberapa referensi dikatakan memang tipe kelainan anatomis yang banyak ditemukan pada subyek laringomalasia adalah tipe 1 yaitu $>50 \%$ kasus yang ditemukan. ${ }^{16}$ pada penelitian ini didapat tipe 1 laringomalasia sebesar $67,7 \%$

Beberapa faktor komorbiditas laringomalasia adalah kelainan struktural/anatomik saluran laring, yaitu kelemahan otot-otot laring disertai dengan adanya kelainan sistem saraf pusat (SSP), kelainan genetik, penyakit jantung bawaan, GERD/RLF. Empat faktor komorbiditas utama yang menyertai laringomalasia adalah kelainan SSP, kelainan genetik, adanya GERD/RLF dan kelainan jantung bawaan. Penyakit penyerta tersebut umumnya ditemukan pada laringomalasia gejala sedang sampai berat. Penyakit penyerta yang paling banyak adalah RLF atau GERD, $25 \%-50 \% .^{21,22}$

Subyek dengan laringomalasia 25\%-50\% akan disertai adanya RLF atau gastroesofageal reflux diseases (GERD). ${ }^{8}$ Diagnosis RLF dapat dilakukan dengan pemeriksaan laryngoscopy flexible bila ditemukan minimal 3 dari tanda klinis, yaitu obliterasi ventrikular, edem vocal fold dan adanya edem difus pada laring. Diagnosis baku emas RLF/GERD adalah dengan pemeriksaan ambulatory 24-hour double probe pH monitoring. Namun, pada penelitian ini tidak dilakukan konfirmasi dengan pemeriksaan pHmetri karena pemeriksaan ini merupakan prosedur yang invasif dan tidak rutin dilakukan serta memiliki sensitivitas yang rendah dengan negatif palsu $\pm 50 \%$ $80 \%$ sehingga pesedur pemeriksaan pHmetri hanya disarankan untuk pasien yang tidak responsif terhadap terapi supresi asam lambung, dan umumnya diagnosis GERD hanya berdasar gambaran klinis saja. ${ }^{23,24}$

Berdasarkan skor RFS, nilai RLF positif 12 . Angka prevalensi ini lebih rendah dibanding beberapa referensi, dimungkinkan karena pemeriksaan untuk memastikan penyakit GERD secara baku termasuk melakukan pemeriksaan pHmetri tidak dilakukan.

Nilai prediktif pemeriksaan laringoskopi adalah 100\% untuk diagnosis RLF. Penggunaan laryngoscopy flexible digunakan untuk menilai 7 item, yaitu hipertofi tonsil lingual, edem subglotis (pseudosulcus) dan eritem subglotis, edem dan eritem ariteniod, obliterasi plika ventrikular, edem dan lesi plika vokalis dan cobblestoning dinding faring posterior. Perbedaan dengan penilaian berdasarkan sistem skoring RFS yang menilai 8 item dari 7 item sebelumnya adalah tidak menilai derajat hipertrofi tonsil lingual. ${ }^{16}$

Subyek dengan laringomalasia juga perlu dipastikan diagnosis adanya RLF atau GERD berdasar hasil pemeriksaan laringoskopi dengan menggunakan skor RFS, komponen yang dapat dinilai skor RFS pada anak adalah komponen 1) obliterasi ventrikular (nilai 2 parsial dan 4 bila komplit), 2) edem vocal fold (nilai1 bila edem ringan, nilai 2 bila edem sedang dan nilai 3 bila edem berat serta nilai 4 bila terdapat polipoid) dan 3) edem difus pada laring (nilai 1 bila edem ringan, nilai 2 bila edem sedang dan nilai 3 bila edem berat serta nilai 4 bila terdapat obstruksi laring) nilai sugestif bila nilai RFS >4 dengan kemungkinan nilai maksimal 12.

Paparan asam lambung dan pepsin berulang pada mukosa laringofaring pada pasien dengan RLF atau 
GERD menyebabkan inflamasi dan gangguan sensoris mukosa laringofaring. ${ }^{25}$ Karena itu timbul dugaan kuat hubungan patofisiologi inflamasi laring dengan RLF, fungsi sensoris, dan laringomalasia. Refluks laringofaring menyebabkan inflamasi dan disfungsi saraf yang berperan dalam memperberat gejala laringomalasia. ${ }^{26}$ Studi Aviv $^{27}$ melaporkan perbaikan bermakna defisit sensoris laringofaring pada pasien dengan gangguan menelan dan edem laring posterior akibat RLF dengan pemberian obat PPI. Dari pemeriksaan laryngoscopy flexible dapat ditemukan berbagai kelainan laring yang berhubungan dengan RLF. Pseudo ulkus vokalis dibuktikan oleh Hickson ${ }^{28}$ merupakan ramalan yang akurat pada RLF dengan nilai predikstif positif $90 \%$. Belafsky ${ }^{29}$ melaporkan bahwa RFS secara akurat mendemonstrasi efektifitas terapi pada pasien RLF dan memiliki inter dan intra observer reproducibility terbaik dan banyak studi yang telah menggunakan RFS sebagai modalitas diagnosis RLF.

Penilaian skor LSS telah dibuktikan mempunyai validitas dan reabilitas yang baik serta mudah dilaksanakan dalam menilai gejala laringomalasia. Kuesioner LSS mudah dimengerti berdasar keluhan yang ditanyakan pada orang tua atau keluarga yang membawa anak berobat, tetapi juga bersifat subyektif dan dapat bervariasi antara individu dan sangat dipengaruhi banyak faktor, seperti latar belakang pendidikan dan pekerjaan. Laryngomalacia symptom score yaitu pengukuran kualitas laringomalasia berdasar sistem skoring. Setiap gejala laringomalasia dapat di beri nilai skoring (1) bila ada gejala dan (0) bila tidak terdapat gejala sebagai berikut stridor inspirasi, retraksi suprasternal, retraksi substernal, kesulitan feeding, chocking, muntah setelah feeding, gagal tumbuh (failure to thrive) dan sianosis. Oleh karena itu, setiap pasien bila dikalkulasi total skor gejalanya mempunyai nilai 8 bila ada semua gejala dan nilai 0 bila tidak ada gejala. Nilai LSS bermakna bila nilai awal sebelum intervensi terapi atau tindakan bila nilai skoringnya $\geq 2$.

Rerata nilai LSS akhir penelitian adalah 3,38 $\pm 1,18$. Jika dikategorikan berdasar adanya perbaikan atau tidak ada perbaikan, pada gejala ringan 11 subyek mengalami perbaikan dan 14 tidak mengalami perbaikan. Pada kedua kelompok, persentase tidak ada perbaikan lebih tinggi dibandingkan ada perbaikan gejala. Pada kasus berat, 10 subyek mengalami perbaikan dan 7 tidak mengalami perbaikan. Persentase tidak ada perbaikan lebih tinggi dibanding persentase perbaikan pada gejala ringan. Sebaliknya, pada gejala berat persentase perbaikan lebih tinggi. Tampak perubahan nilai LSS awal dan akhir. Prevalensi RLF atau GERD 24,6\%. $\mathrm{Hal}$ ini sesuai dengan penelitian sebelumnya yang memperoleh prevalensi laringomalasia hampir 25\%$50 \%$ akan disertai adanya RLF atau GERD. ${ }^{8}$

Penilaian daerah laring pada orang dewasa dilakukan berdasarkan nilai RFS menurut Belafsky dengan skala 0 sampai 26 dan nilai $>7$ dinyatakan sebagai positif RLF dengan nilai spesifitas $95 \%$. Sistem skoring pada anak belum divalidasi sehingga hanya dapat menilai tanda klinis daerah hifofaring dan laring. May dalam studi systemic review 8 literatur mengenai hubungan penemuan klinis laring dan trakea pada populasi anak penderita GERD dengan komplikasi supraesofagus RLF menyatakan edem dan hiperemi aritenoid, hipertrofi tonsil lingual, edem postglotik dan edem plika vokalis terbukti mempunyai hubungan bermakna dengan RLF. ${ }^{11}$ Nasution ${ }^{17}$ juga melaporkan 3 item dari RFS yang mempunyai skor bermakna pada bayi dan anak, yaitu adanya obliterasi ventrikular, edem plika vokalis dan edem laring difus. Berdasarkan penilaian tersebut dengan tetap menggunakan skoring RFS menurut Belafsky, maka nilai positif RLF adalah $>4$ dengan skala 0 sampai 12 . Rerata nilai RFS awal 3 dengan rentang 2-10. Bila dikategorikan ada tidaknya RLF maka pada awal penelitian jumlah pasien RLF positif 12 subyek. Rerata nilai RFS pada akhir penelitian berubah dengan nilai 2 dengan perubahan rentang $0-8$. Tampak perubahan bermakna bila dibandingkan nilai RFS awal dan akhir.

Pada laringomalasia ringan akan sembuh sendiri tanpa tindakan spesifik, cukup dengan tindakan suportif. Gejala akan berkurang secara bertahap saat usia mencapai 12-18 bulan, sebagian lagi hingga usia 2 tahun. ${ }^{1,30-31}$ Pada laringomalasia, gejala sedang dapat diberikan terapi acid supression dan modifikasi pemberian makan. Terapi acid supression adalah pemberian antagonis reseptor $\mathrm{H} 2$ (ranitidin $3 \mathrm{mg} / \mathrm{kgbb}$ tiga kali perhari) atau pemberian PPI yaitu omeperazol $1-3 \mathrm{mg} / \mathrm{kgbb}$ satu kali perhari saat malam hari. Pada kasus yang memberat dapat diberikan kombinasi yaitu omeperazol 1-3 mg/kgbb saat pagi hari dan ranitidin 6 $\mathrm{mg} / \mathrm{kgbb}$ saat malam hari. Belum ada studi prospektif yang menjelaskan berapa lama terapi acid supression pada anak. ${ }^{11,16,32-34}$ Menurut Thompson, ${ }^{8}$ umumnya anak dengan laringomalasia membutuhkan terapi selama lebih kurang 9 bulan (1-38 bulan).

Saat ini, PPI dijadikan pilihan utama dalam terapi farmakologi RLF. Dampak yang optimal bila diberikan 
30-60 menit sebelum makan. Woo ${ }^{35}$ melaporkan bahwa pemberian dengan regimen 2 kali perhari lebih baik daripada pemberian 1 kali perhari. Alasan diperlukan dosis 2 kali perhari disebabkan bahwa obat PPI efek supresi asam lambung ( $\mathrm{pH}=4$ intragastrik) hanya efektif dalam 16,8 jam sehingga dengan pemberian 2 kali perhari diharapkan akan tercapai konsentrasi steadystate dan biasanya lebih baik mengontrol paparan asam lambung pada siang dan malam hari serta dari beberapa data dinyatakan bahwa 25\%-40\% pasien tidak berespon dengan pemberian satu kali perhari. ${ }^{36,37}$

Efektifitas omeperazol pada laringomalasia dari laporan sebelumnya masih kontroversi. Terdapat anggapan bahwa laringomalasia akan membaik sendiri dengan bertambahnya usia anak. Efektifitas obat omeperazol yang ditemukan pada penelitian ini serta tidak terbuktinya peran omeperazol untuk mencegah kejadiannya dapat dipengaruhi oleh keutuhan faktor protektif yang dimiliki anak. Belum ada penelitian lain yang melaporkan kemungkinan adanya faktor protektif spesifik pada anak yang memengaruhi kejadian laringomalasia.

Pola diet yang dapat memengaruhi keseimbangan jumlah dan jenis, serta cara pemberian pada individu tidak diteliti pada penelitian ini. Laporan mengenai peran efektifitas omperazol dalam pengobatan laringomalasia secara umum, ataupun meneliti manfaatnya dalam mencegah memperberat laringomalasia secara khusus pada anak dengan pemberian jangka panjang masih sangat terbatas, meskipun telah banyak laporan penelitian mengenai efektivitasnya dalam pencegahan dan atau terapi pada kasus GERD dan RLF.

Masalah lain adalah heterogenitas penelitian sehingga belum ada kesepakatan mengenai jenis obat PPI yang dipakai, dosis, maupun durasi ideal PPI untuk masing-masing masalah klinis tersebut. Pada penelitian ini, PPI yang digunakan adalah omeperazol dengan dosis $2 \mathrm{mg} / \mathrm{kgbb} /$ diberikan 2 kali sehari setiap hari selama 3 bulan. Stabilitas dan viabilitas omeperazol merupakan masalah lain yang perlu menjadi perhatian. Berbagai faktor dapat memengaruhi stabilitas dan viabilitas omeperazol yang dikonsumsi. Faktorfaktor tersebut mencakup tahapan pengolahan, penyimpanan, dan transportasi obat omeperazol sebelum dikonsumsi maupun faktor pengaruh asam lambung, asam empedu, dan enzim pankreas dalam usus setelah omeperazol dikonsumsi. Faktor lain yang mungkin memengaruhi efektifitas omeperazol adalah kecenderungan metabolisme omeprazol yang lebih tinggi pada anak. ${ }^{38}$

Subyek dengan status gizi kurang dan gizi buruk marasmik menggambarkan subyek dengan laringomalasia juga disertai dengan problem gagal tumbuh (failure to thrive) karena terdapat kesulitan feeding, menelan, dan muntah yang dialami subyek. Kondisi malnutrisi berat dengan imunodefisiensi dapat merupakan merupakan faktor primer atau sekunder akibat adanya laringomalasia. Kondisi ini, baik berupa kelemahan otot laring dan gangguan menelan serta sering muntah dapat mempengaruhi kondisi status gizi anak sehingga dapat menimbulkan terjadinya penyebab malnutrisi baik makro nutrien maupun mikro nutrien sudah banyak dilaporkan dalam berbagai penelitian dan hal ini terjadi sebagai akibat gangguan menelan dan sering muntah yang ditimbulkannya. ${ }^{1}$

Keberhasilan terapi dinilai berdasar derajat penyakit dan penambahan berat badan. Whymark ${ }^{20}$ melaporkan bahwa penambah berat badan merupakan penilaian objektif yang dapat distandarisasi sesuai dengan kurva usia persentil berat badan. Sebagian besar subyek pada awal penelitian ini memiliki status nutrisi gizi kurang, gizi buruk marasmik, dan gizi lebih. Kondisi akhir penelitian bila dikategorikan ada tidaknya perbaikan dengan adanya perbaikan, pada status gizi baik dan obesitas 2 subyek mengalami perbaikan dan 6 tidak mengalami perbaikan. Pada status gizi buruk marasmik dan gizi kurang 19 subyek mengalami perbaikan dan 15 tidak mengalami perbaikan. Hal lain selain pemberian omperazol, perbaikan ini masih dimungkinkan karena intervensi penanganan gizi oleh bagian gizi anak termasuk edukasi gizi dan pemasangan nasal gastrointestinal tube, terutama pada bayi dengan status gizi buruk marasmik.

\section{Kesimpulan}

Sebaran karakteristik subyek penelitian laringomalasia berdasar jenis kelamin lebih banyak ditemukan pada anak laki-laki dibandingkan perempuan. Terdapat perbedaan berdasar perbandingan nilai awal dan akhir RFS, juga berdasar nilai LSS. Hasil penelitian pendahuluan ini sesuai dengan harapan, tetapi dengan keterbatasan jumlah sampel yang tidak terpenuhi karena keterbatasan waktu penelitian dan jejaring.Diagnosis refluks laringofaring pada bayi dan anak sulit karena 
Riza Sahyuni dkk: Efektifitas pemberian proton pump inhibitor (omeperazol) pada bayi dan anak dengan laringomalasia

belum ada standar baku berdasar penilaian laringoskopi. Pemeriksaan dan penentuan diagnosis laringomalasia dan refluks laringofaring seharusnya dilakukan oleh satu orang operator atau observer, Kepatuhan minum obat dan keteraturan minum obat seharusnya dapat dijamin dengan mempergunakan check-list dan dapat dipantau secara langsung oleh peneliti.

\section{Daftar pustaka}

1. Affandi NB, Widyaningsih. Buku Ajar Respirologi Anak Edisi I. Jakarta : UKK Respirologi PP IDAI; 2013.h.398-401.

2. Landry AM, Thompson DM. Laryngomalcia: Disease presentation, spectrum and management. Int J Pediatr 2011;120:99-103.

3. Daniel M, Cheng A. Neonatal stridor. Int J Pediatr 2012;2012:859104. h 1-5

4. Yee-Hang WB, Theresa H, So-lun L, Wai-Kuen H, Ignace WW. Stridor in Asian infants: Assesment and treatment. ISRN Otolaryngiol 2012;2012:915910. h 1-4

5. Srivastava R. Role of Radiofrequency cautery in laryngomalacia : a study in 12 patients. Indian J Otolaryngol Head \& Neck Surg 2010; 62:386-9.

6. Kelley PE. Laryngomalacia. Dalam : Freidman penyunting. Sleep apnea and snoring surgical and non surgical therapy. Chicago: Saunders Elsevier ;2009.h.437-43.

7. Reix P, St-Hilaire M, Praud JP. Laryngeal sensitivity in the neonatal period. Pediatric Pulmonol 2007;42:674-82.

8. Thompson DM. Laryngomalacia : factors that influence disease severity and outcomes of management. Curr Opinion Otolaryngol \& Head and Neck Surg 2010;18:564-70.

9. Lovinsky-Desir S, Bye MR, Laryngomalacia. Diakses pada 18 Juni 2015. Diunduh dari: http://emedicine, medscape.com.

10. Lipan MJ, Reindenberg JS, Laitman JT. Anatomy of reflux. a growing health problem affecting structures of head and neck. The Anatomical record part B : The New Anatomist 2006;289:261-70.

11. May JG, Shah P, Lemonnier L, Bhatti G, Koscica J, Coticchia JM. Systemic review of endoscopic airway findings in children with gastroesophageal reflux disease. Ann Otology, Rhinilogy \& Laryngology 2011;120:116-20.

12. El-sayed Ali M. Laryngopharyngeal reflux: diagnosis and treatment of a controversial disease. Curr Opinion Allerg Clin Immunol 2008;8:28-33.

13. Rees CJ, Belafsky PC. Laryngopharyngeal reflux. Dalam : Leonard R. Kendall K, penyunting. Dysphagia assesment and treatment planning a team approach. Edisi ke-2. Sandiego: Plural publishing;2008. h.71-85.
14. Bach KK, McGuirt WF, Postma GN. Pediatric laryngopharyngeal reflux. ENT (ear, nose \& throat) J 2002;81:27-31.

15. Stavroulaki P. Diagnostic and management problems of laryngpharyngeal reflux disease in children. Int J Pediatr Otorhinolaryngol 2006;70:597-9.

16. Thompson DM. Abnormal sensorimotor integrative function of the larynx in congenital larygomalacia : a new theory of etiologi. The Laryngoscope 2007;117:1-33.

17. Nasution D P. Prevalensi refluks laringofaring pada bayi laringomalasia primer di RSCM. Tesis PPDS Ilmu Penyakit Telinga Hidung Tenggorok (THT) FK Universitas Indonesia. Jakarta 2012

18. Edmondson NE, Bent JP, Chan C. Laryngomalacia : The Role gender and etnicity. Inter J Pediatric Otorhinolaryngol 2011;75:1562-4

19. Becklake MR, Kaufmann F. Gender differences in airway behavior over the human life span. Thorax BMJ 1999;54:111938

20. Whymark AD, Clement WA, Kubba H, Geddes NK. Laser epiglottoplexy for laryngiomalacia, 10 years experience in the west of scotland. Arch Otolaryngol Head Neck Surg 2006;132:978-82.

21. Praud JP. Upper airway reflexes in response to gastric reflux. Pediatric Respiratory Rev 2010;11:208-12.

22. Chandra RK, Gerber ME, Holinger LD. Histological insight into the pathogenesis of severe laryngomalacia. Int J Pediatr Otorhinolaryngol 2001;61:31-8.

23. Lee KS, Chen BN, Yang CC, Chen YC. CO2 laser supraglotoplasty for severe laryngomalacia : a study of symptomatic improvement. Int J Pediatr Otorhinolaryngol 2007;71:889-95.

24. Shockley WW, Das S. Esophageal disorders. Dalam: Byron JB, Jonas JT, Shawn ND, penyunting. Head \& neck surgery otolaryngology. Edisi ke-4. Philadelpia: Lippincott Williams \& Wilkins 2006.h.755-70

25. Payne RJ, Kost KM, Frenkiel S, Zeitouni AG, Sejean G, Sweet $\mathrm{RC}$, dkk. Laryngeal inflammation assessed using the reflux finding score in obstructive sleep apnea. American academy of otolaryngology head \& neck surgery 2006;134:836-42.

26. Ayari S. Aubertin G, Girschig H, Van den A T, Mondain M. Patophysiology and diagnostic approach to laryngomalacia in infants. Eur ann Otorhinolaryngol Head \& Neck Disease 2012;129:257-63.

27. Aviv JE, Liu H, Kaplan ST, Parides M, Close LG. Laryngopharyngeal sensory deficits in patients with laryngopharyngeal reflux and dysphagia. Ann Otol Rhinol Laryngol 2000;109:1000-6.

28. Hickson C, Simpson BC, Falcon R. Laryngeal pseudoulcus as a predictor of laryngo-pharyngeal reflux. The Laryngoscope 
2001;111:1742-5.

29. Belafsky PC, Postma GN, Koufman JA. The validity and reliability of the reflux finding score (RFS). The Laryngoscope 2001;111:1313-7.

30. Johnston N, Bulmer D, Gill GA, Panetti M, Ross PE, Pearson JP et al. Cell biology laryngeal epithelial defenses in health and disease; Further studies. Ann Otol Rhinol Laryngol 2003;112:481-91.

31. Brodsky L, Carr MM. Extraesophageal reflux in children. Curr Opin Otolaryngology Head \& Neck Surg 2006;14:387-92.

32. Muller A. Reconstructive procedures for impaired upper airway: laryngeal respiration. GMS Curr Topics in Otorhinolaryngol Head \& Neck Surg 2005;4:1-29.

33. Munson PD, Saad AG, El-Jamal SM, Dai Y, Bower CM, Ritcher GT. Submucosal nerve hypertrophy in congenital laryngomalacia. The Laryngoscope 2011;121:627-9.

34. Ritcher GT, Thompson DM. The Surgical management of laryngomalacia. Otolaryngologic Clinics of North America 2008;41:837-64.

35. Woo P, Yanagisawa E. The larynx, Dalam : Lee K.J penyunting, Essential otolaryngology head \& neck surgery. Edisi ke-8. New York. Mcgraw-Hill; 2003:724-36.

36. Koufman JA, Aviv JE, Casiano RR, Shaw GY. Laryngopharyngeal reflux: position statement of the committee on speech, voice and swallowing disorders of the American Academy of otolaryngology-head \& neck surgery. Otolaryngol Head Neck Surg 2002.127;32-5.

37. Patigaroo SA, Hashmi SF, hasan SA, Ajmal MR, Mehfooz N. Clinical manifestations and role of proton pump inhibitors in the management of laryngopharyngeal reflux. Indian..J Otolaryngol Head Neck Surg 2011;63:182-9.

38. Anderson T, Hassal E, Lundborg P, Sheperd R, Radke M, Marcon M, dkk. Pharmaco-kinetics of orally administered omeprazole in children. Am J Gastroenterol 2000;95:3101-6. 